\title{
PENGARUH KONDISI FUNDAMENTAL, INFLASI DAN SUKU BUNGA SERTIFIKAT BANK INDONESIA TERHADAP HARGA SAHAM (Studi Kasus Perusahaan Real Estate Dan Property Yang Terdaftar Di Bursa Efek Indonesia)
}

\author{
Okinawa Syahfitri, Aminar Sutra Dewi \\ Sekolah Tinggi Ilmu Ekonomi KBP \\ okinawasyahfitri@gmail.com
}

\begin{abstract}
The stock price is a reflection of the value of the company. Stock price fluctuations can not only be influenced by company fundamentals but also influenced by the macro economy of a company. In this study aims to determine the effect of fundamental conditions, inflation and sbi interest rates on stock prices. The data used is secondary data. This study selects data on the real estate and property industry that are listed on the Indonesian stock exchange with the observation period of 2015-2017. The method of sample collection uses a purposive sampling method which obtained 22 companies studied. The analytical method used is panel data regression, which is the Random Effect Models (REM) test. The results of this study show that the fundamental conditions with ROA have a significant effect on stock prices, EPS has a significant effect on stock prices, $P B V$ has a significant effect on stock prices, DER has a significant effect on stock prices and SBI Interest Rate has a significant effect on stock prices whereas Inflation has no effect significant to stock prices.
\end{abstract}

Keywords: Stock Prices, Fundamental Conditions, Inflation, SBI Interest Rates

\section{PENDAHULUAN}

Harga saham dapat diartikan jumlah atau harga dari surat berharga yang dimiliki perusahaan yang akan dibeli oleh emiten berdasarkan penilaiannya terhadap perusahaan. Dalam dunia usaha harga saham perusahaan adalah suatu patokan dimana apakah perusahaan akan mengalami perkembangan atau tidaknya. Apabila harga saham tinggi itu menggambarkan perusahaan tersebut mempunyai peluang perkembangan perusahaan dan apabila harga saham turun maka perusahaan tersebut akan mengalami kurangnya investasi dari investor yang mengakibatkan terganggunya perkembangan perusahaan. (Hutami, 2012).

Harga saham pada penelitian dipengaruhi oleh kondisi fundamental, analisis fundamental merupakan analisis yang berdasarkan faktor fundamental perusahaan yang ditunjukkan dalam laporan keuangan perusahaan. Atas dasar laporan keuangan para investor dapat melakukan penilaian kinerja keuangan perusahaan terutama dalam hal melakukan investasi. Analisis fundamental yang dipakai untuk memprediksi harga saham adalah rasio keuangan. Alat analisis rasio keuangannya yang dignakan yaitu: return on asset (ROA), return on equity $(R O E)$, price to book value $(P B V)$, earning per share $(E P S)$ dan debt equity ratio $(D E R)$. Selain faktor fundamental perusahaan, ada beberapa makro ekonomi 
lainnya yang dapat mempengaruhi harga saham yaitu inflasi dan suku bunga sbi (Wardani \& Andarini, 2016).

Inflasi merupakan indikator ekonomi yang menyebabkan kenaikan harga barang dan jasa dalam suatu periode. Adanya inflasi yang tinggi akan menyebabkan naiknya biaya produksi. Suku bunga SBI adalah instrumen suku bunga yang dikeluarkan oleh BI untuk mengontrol peredaran uang di masyarakat (Rismawati, 2010) dalam (Dek et al., 2016). Menurut Sadono (2006), suku bunga adalah persentase pendapatan yang diterima oleh kreditur dari pihak debitur selama interval waktu tertentu.

Bisnis real estate dan property adalah bisnis yang dikenal memiliki karakteristik cepat berubah (volatile), persaingan yang ketat. Banyak masyarakat menginvestasikan modalnya di ind ustri real estate dan property dikarenakan harga tanah yang cenderung naik. Penyebabnya adalah supply tanah bersifat tetap sedangkan demand akan selalu bertambah besar seiring dengan pertambahan jumlah penduduk serta bertambahnya kebutuhan manusia akan tempat tinggal, perkantoran, pusat perbelanjaan, dan lain-lain. Seiring dengan itu, perusahaan real estate dan property yang go public terus bertambah di Indonesia. Perkembangan real estate dan property di Indonesia dapat terlihat dari perubahan atau fluktuasi harga saham dari tahun ke tahunnya. Oleh karena adanya harga saham yang tidak stabil atau mengalami fluktuasi maka hal tersebut membuat peneliti ingin meneliti kembali apa yang menyebabkan harga saham tersebut mengalami penurunan dan kenaikan harga (Dek et al., 2016).

Analisis fundamental merupakan analisis yang berdasarkan faktor fundamental perusahaan yang ditunjukkan dalam laporan keuangan perusahaan. Atas dasar laporan keuangan para investor dapat melakukan penilaian kinerja keuangan perusahaan terutama dalam hal melakukan investasi (Wardani \& Andarini, 2016). Kondisi fundamental akan mempengaruhi harga saham perusahaan dengan fluktuasinya yang akan di lihat oleh investor dalam melakukan pembelian saham.

Return on Asset (ROA) digunakan untuk mengetahui besarnya laba bersih yang dapat diperoleh dari opersional perusahaan dengan menggunakan seluruh kekayaannya. Semakin bagus ROA semakin efisien operasional perusahaan dan begitu demikian sebaliknya. ROA yang positif menunjukkan bahwa dari total aset yang digunakan untuk operasional perusahaan mampu memberikan laba bagi perusahaan.

Hasil penelitian (Almas, 2007) yang berjudul analisis faktor fundamental dan resiko sistimatik terhadap harga saham properti di Bursa Efek Jakarta, juga menyatakan bahwa faktor fundamental yang terdiri dari return on assets (ROA) memiliki pengaruh positif signifikan terhadap harga saham perusahaan properti di bej. Dan penelitian Budialim, (2013) menemukan hasil yang sama dimana return on assets (ROA) mempengaruhi harga saham secara signifikan dan positif. Berdasarkan penjelasan diatas maka hipotesis dalam pengamatan ini dirumuskan : $\mathrm{H}_{1}$ : Diduga ROA berpengaruh positif dan signifikan terhadap harga saham

Price to Book Value (PBV) merupakan perbandingan antara harga pasar persaham dan nilai buku persaham. Semakin besar rasio PBV semakin tinggi perusahaan dinilai oleh para pemodal relatif dibandingkan dengan dana yang telah ditonamkan di perusahaan (Husnan dan Pudjiastuti, 2006:258) dalam (Suselo, 2015). Oleh karena itu, semakin tinggi rasio PBV, makin berhasil dan mampu 
perusahaan menciptakan nilai bagi pemegang saham, dimana semakin tinggi tingkat kepercayaan pasar terhadap prospek perusahaan, sehingga permintan akan saham tersebut naik, kemudian mendorong kenaikan harga saham perusahaan tersebut.

Hal ini didukung oleh penelitian yang sebelumnya telah dilakukan oleh Rahmi, et al. (2013) yang berjudul pengaruh faktor-faktor fundamental dan risiko sistematik terhadap harga saham, yang hasil penelitiannya menyimpulkan bahwa variabel PBV memiliki pengaruh signifikan dan positif terhadap harga saham. Dan juga pada penelitian (Itabillah, 2013), tentang pengaruh $C R, Q R, N P M$, ROA, EPS, ROE, DER dan PBV terhadap harga saham perusahaan property dan real estate yang terdaftar di BEI. Hasilnya menunjukkan bahwa price to book value (PBV) memiliki pengaruh signifikan positif terhadap harga saham. Berdasarkan penjelasan diatas maka hipotesis dalam penelitian ini dirumuskan : $\mathrm{H}_{2}$ : Diduga price to book value berpengaruh positif dan signifikan terhadap harga saham.

Menurut Darmadji (2012:97), rasio EPS menunjukkan besarnya keuntungan yang dapat didapatkan pemegeng saham per lembar saham yang dimiliki. Semakintinggi nilai EPS merupakan kabar baik bagi pemegang saham karena semakin besar laba yang akan diperoleh pemegang saham (Dek, Roshita, Gede, \& Artini, 2016). Pada penelitian (Widaningsih, 2013) yang berjudul pengaruh ROA, DER, EPS, DPS terhadap harga saham menemukan hasil bahwa secara parsial EPS memiliki pengaruh positif dan signifikan terhadap harga saham. Hasil yang sama pada penelitian (Itabillah, 2013) yang berjudul pengaruh $C R, Q R, N P M, R O A, E P S, R O E, D E R$ dan PBV terhadap harga saham perusahaan property dan real estate yang terdaftar di BEI. Hasil penelitian menunjukkan bahwa price to book value (PBV) memiliki pengaruh signfikan positif terhadap harga saham. Dari penjelasan diatas, maka hipotesis dalam penelitian ini dirumuskan :

$\mathrm{H}_{3}$ : Diduga earning per share berpengaruh positif dan signifikan terhadap harga saham.

Menurut Husnan, (2009) rasio debt to equiy ratio (DER) digunakan untuk mengukur kemampuan perusahaan dalam melunasi utang dengan modal yang dimiliki. Sudana, (2011) menyatakan bahwa semakin besar penggunaan utang dibandingkan dengan modal sendiri menyebabkan penurunan nilai perusahaan tersebut. Investor cenderung akan menghindari berinvestasi pada perusahaan dengan DER yang tinggi karena semakin tinggi penggunan hutang maka dividen yang seharusnya dibagikan kepada pemegang saham akan berkurang karena laba yang diperoleh digunakan untuk membyar utang perusahaan.

Teori tersebut diperkuat oleh hasil penelitian yang dilakukan oleh (Ratih, 2013) yang berjudul pengaruh EPS, PER, DER dan ROE terhadap harga saham pada perusahaan pertambangan yang terdaftar di BEI, dimana hasilnya menyatakan bahwa DER berpengaruh negatif signifikan terhadp harga saham. Pada penelitian (Widaningsih, 2013) yang berjudul pengaruh ROA, DER, EPS, DPS terhadap harga saham pada perusahaan indeks LQ45 yang terdaftar di BEI. Hasil penelitian menunjukkan bahwa DER berpengaruh signifikan dan negatif terhadap harga saham. Berdasarkan penjelasan diatas, maka hipotesis dalam penelitian ini dirumuskan : 
$\mathrm{H}_{4}$ : Diduga debt equity ratio berpengaruh negatif dan signifikan terhadap harga saham

Tingkat inflasi yang tinggi biasanya akan dikaitkan dengan kondisi ekonomi yang overhead atau dapat diartikan kecenderungan kenaikan harga barang akibat terlalu tingginya tingkat permintaan atas produk hingga melebihi kapasitas penawaran produknya Tandelilin, (2010). Pada penelitian dari Aurora, (2013) yang berjudul pengaruh inflasi, suku bunga dan kurs terhadap indeks LQ45 di BEI dan penelitian Sihaloho, (2013) pengaruh inflasi, suku bunga, dan book value (BV) terhadap harga saham perusahaan Indeks LQ45 yang terdaftar di BEI menemukan bahwa inflasi berpengaruh negatif signifikan terhadap harga saham. Dan penelitian Thobarry, (2009) yang berjudul analisis pengaruh nilai tukar, suku bunga, laju inflasi dan pertumbuhan GDP terhadap indeks harga saham sektor properti, menunjukkan bahwa inflasi berpengaruh negatif signifikan terhadap indeks harga saham properti, sama halnya dengan penelitian yang dilakukan oleh Prihantini (2009) yang menunjukkan bahwa inflasi berpengaruh negatif dan signifikan terhadap return saham. (Wardani \& Andarini, 2016). Berdasarkan penjelasan diatas maka hipotesis dalam penelitian ini dirumuskan : H5 : Diduga Inflasi berpengaruh negatif dan signifikan terhadap harga saham

Suku bunga yang tinggi akan menyebabkan semakin tingginya bunga kredit pinjaman di industri real estate dan property, dengan demikian maka minat para konsumen menurun dan mengakibatkan rendahnya harga saham pada industri ini. Pada penelitian Perdana, (2009) yang berjudul pengaruh suku bunga sbi dan kurs rupiah serta inflasi terhadap harga saham. Hasil penelitian menunjukkan bahwa suku bunga SBI juga berpengaruh negatif terhadap harga saham, dan penelitian ini didukung oleh Liauw, (2013) yang berjudul analisis pengaruh tingkat inflasi, suku bunga sbi dan nilai tukar rupiah terhadap indeks harga saham gabongan, dimana hasil penelitian berpengaruh negatif dan signifikan terhadap IHSG. Berdasarkan teori dan penelitian terdahulu yang telah dikemukakan sebelumnya maka dapat dirumuskan hipotesis :

$\mathrm{H}_{6}$ : Diduga suku bunga sertifikat bank Indonesia berpengaruh negatif dan signifikan terhadap harga saham.

\section{METODE PENELITIAN}

Jenis pengujian yang diambil pada penelitian ini berupa metode kuantitatif. Metode kuantitatif yaitu data penelitian yang bersifat angka-angka dan dianalisis menggunakan statistik yang tujuannya untuk membuktikan hipotesis yang sudah diterapkan (Sugiyono 2015).

Dalam penelitian ini objek yang dipilih yaitu perusahaan Real Estate dan Property yang terdaftar di Bursa Efek Indonesia (BEI) periode 2015-2017. Karena BEI adalah titik informasi yang pasti mengenai industri yang telah go publik.

Populasi adalah lingkungan penyamarataan yang terdapat objek atau subjek yang punya jumlah dan individualitas terpilih yang diterapkan oleh pengamat untuk pelajari dan selanjutnya di tarik simpulannya (Sugiyono 2015). Populasi pada penelitian ini sebanyak 54 perusahaan real estate dan property yang tercantum pada Bursa Efek Indonesia (BEI) periode 2015-2017.

Sampel adalah komponen dari kuantitas dan ciri-ciri yang ada pada populasi (Sugiyono, 2015). Dalam penelitian ini pemilahan sampel dilakukan 
dengan memakai metode purposive sampling yang berjumlah 22 perusahaan yang diambil berdasarkan kriteria yang ditentukan.

Jenis data yang dipakai pada penelitian ini berupa data sekunder. Data sekunder merupakan suatu data perusahaan yang telah dipublikasikan atau didokumentasikan (Sugiyono 2015). Data sekunder merupakan data yang dapat diperoleh secara tidak langsung dari perusahaan. Tetapi data didapat diluar industri yang telah direkomendasikan. Sumber data yang dipilih pada pengamatan yaitu dari situs resmi Bursa Efek Indonesia (BEI) yang dapat di akses melalui www.idx.co.id dan www.yahoofinance.com

Pada penelitian ini teknik pengumpulan data yang dipilih adalah dokomentasi. Teknik dokumentasi yaitu teknik pengumpulan data-data yang telah menjadi suatu dokumentasi yang telah dipublikasikan seperti laporan keuangan oleh perusahaan pada index LQ45 di Bursa Efek Indonesia melalui situs resmi www.idx.co.id www.yahoofinance.com

\section{Definisi Operasional Variabel}

Variabel yang digunakan dalam penelitian ini adalah variabel bebas (independent variable) dan variabel terikat (dependent variable). Selanjutnya dapat diuraikan definisi operasionalnya dari penelitian ini sebagai berikut:

\section{Tabel 1}

Defenisi Operasional Variabel

\begin{tabular}{|l|l|l|l|}
\hline Variabel & \multicolumn{1}{|c|}{ Defenisi } & \multicolumn{1}{|c|}{ Pengujian } & Sumber \\
\hline $\begin{array}{l}\text { 1. Harga } \\
\text { Saham }\end{array}$ & $\begin{array}{l}\text { Harga saham adalah harga yang } \\
\text { terbentuk sesua permintaan dan } \\
\text { penawaran di } \\
\text { pasar jual beli saham dan } \\
\text { biasanya merupakan harga } \\
\text { penutupan. }\end{array}$ & $\begin{array}{l}\text { Harga penutupan saham } \\
\text { Closing Price }) \text { tiap } \\
\text { perusahaan yang diperoleh } \\
\text { dari harga saham pada } \\
\text { periode akhir tahun. }\end{array}$ & $\begin{array}{l}\text { Setiyono, } \\
(2016)\end{array}$ \\
\hline 2.ROA & $\begin{array}{l}\text { Return on Assets adalah } \\
\text { pengukuran kemampuan } \\
\text { perusahaan secara keseluruhan } \\
\text { didalam mendapatkan } \\
\text { keuntungan dengan jumlah } \\
\text { keseluruhan aktiva yang tersedia } \\
\text { di dalam perusahaan. }\end{array}$ & ROA $=\frac{\text { Laba Bersih }}{\text { Total Aktiva }} \times 100 \%$ & $\begin{array}{l}\text { Kasmir, } \\
(2012)\end{array}$ \\
\hline 3.PBV & $\begin{array}{l}\text { Price to Book Value merupakan } \\
\text { perbandingan antara harga pasar } \\
\text { dan nilai buku saham. }\end{array}$ & PBV $=\frac{\text { Harga Pasar per Saham }}{\text { Nilai Buku per Saham }}$ & $\begin{array}{l}\text { Husnan, } \\
(2009)\end{array}$ \\
\hline 4. EPS & $\begin{array}{l}\text { Earning Per Share adalah rasio } \\
\text { yang membandingkan antara } \\
\text { jumlah earning pemegang saham } \\
\text { dengan jumlih lembar saham } \\
\text { perusahaan. }\end{array}$ & EPS $=\frac{\text { Laba Bersih }}{\text { Jumlah Saham Beredar }}$ & $\begin{array}{l}\text { Tandeilin, } \\
(2010)\end{array}$ \\
\hline
\end{tabular}




\begin{tabular}{|c|c|c|c|}
\hline 5. DER & $\begin{array}{l}\text { Debt Equity Ratio adalah rasio } \\
\text { membandingkan antara total } \\
\text { hutang dengan total aktiva yang } \\
\text { dimiliki peresahaan. }\end{array}$ & DER $=\frac{\text { Total Hutang }}{\text { Total Modal }} \times 100 \%$ & $\begin{array}{l}\text { Ratih, } \\
(2013)\end{array}$ \\
\hline 6. Inflasi & $\begin{array}{l}\text { Perhitungan inflasi memakai } \\
\text { indeks harga. Indeks harga } \\
\text { adalah perbandingan antara } \\
\text { harga rata-rata pada tahun yang } \\
\text { dihitung dan harga rata_rata } \\
\text { pada tahun dasar. }\end{array}$ & $\begin{array}{l}\quad \text { IHn }=\frac{\Sigma \mathrm{Pn}}{\Sigma \mathrm{po}} \times 100 \% \\
\text { dimana : } \\
\text { IHn = Indeks harga } \\
\text { Pn = Harga sekarang } \\
\text { Po = Harga tahun dasar }\end{array}$ & $\begin{array}{l}\text { Purwanto, } \\
\text { (2006) }\end{array}$ \\
\hline $\begin{array}{l}\text { 7.Suku } \\
\text { Bunga } \\
\text { SBI }\end{array}$ & $\begin{array}{l}\text { Data tingkat suku bunga SBI } \\
\text { yang diperoleh dalam periode } \\
\text { harian akan diubah menjadi } \\
\text { periode bulanan. }\end{array}$ & $\begin{array}{l}\text { Rata-rata tingkat suku } \\
\text { bunga SBI = Jumlah tingkat } \\
\text { suku bunga periode harian } \\
\text { selama } 1 \text { bulan dibagi } \\
\text { dengan jumlah periode } \\
\text { waktu selama } 1 \text { bulan. }\end{array}$ & $\begin{array}{l}\text { Sarono, } \\
\text { (2014) }\end{array}$ \\
\hline
\end{tabular}

\section{Teknik Analisis Data}

\section{Statistik Deskriptif}

Statistik deskriptif adalah statistik yang berfungsi untuk mendeskripsikan atau memberikan gambaran terhadap ojek yang diteliti melalui data sampel atau populasi sebagaimana adanya, tanpa melakukan analisis dan membuat kesimpulan yang berlaku untuk umum. Pada statistik deskriptif ini, akan dilakukan cara-cara penyajian data, dengan tabel biasa ataupun distribusi frekuensi ; grafik garis maupun batang ; diagram lingkaran ; pictigram ; penjelasan kelompok melalui modus, median, mean dan variasi kelompok melalui rantang dan simpangan baku (Sugiyono, 2015).

\section{Uji Asumsi Klasik}

\section{Uji Normalitas}

Uji normalitas bertujuan menguji apakah dalam model regresi, variabel pengganggu atau residual memiliki residual normal atau tidak. Uji normalitas data bertujuan untuk mengetahui apakah distribusi penyampelan variabel yang digunakan dalam penelitian telah terdistribusi normal atau tidak normal (Fahruri, 2017). Uji normalitas pada penelitian ini menggunakan Jarque-Bera. Dimana apabila Jarque-Bera > tingkat alpha 5\% maka data terdistribusi secara normal dan sebaliknya apabila Jarque-Bera < tingkat alpha 5\% maka tidak terdistribusi normal (Winarno, 2015).

\section{Uji Multikolinearitas}

Uji mulikolonieritas dilakukan guna mengetahui indikasi asumsi klasik tersebut. Uji ini bertujuan menguji apakah model regresi ditemukan adanya pengaruh antar variabel bebas atau independent (Fahruri, 2017). Uji multikolonieritas kondisi adanya hubungan linerar antarvariabel independen (Winarno, 2015). Syarat tidak terjadi Multikolonieritas adalah jika nilai korelasi antar variabel independ $n<0,8$. Jika nilai korelasi $>0,8$ maka terjadi multikolonearitas. 


\section{Uji Pemilihan Model}

\section{Metode Common Effect (CEM)}

Ruri (2007) menyatakan bahwa Model Common Effect menggabungkan data cross section dengan time series dan menggunakan metode OLS untuk mengastimasi model data panel tersebut. Model ini merupakan model paling sederhana dibandingkan dengan kedua model lainya. Model ini tidak dapat membedakan varians antara silang, dan bukan bervariasi secara random.

\section{Metode Fixed Effect (FEM)}

Model Fixed Effect adalah model dengan intercept berbeda-beda untuk setiap subjek (cross section), tetapi slope setiap sujek tidak berubah seiring waktu. Model ini mengasumsikan bahwa intercept adalah berbeda setiap subjek lainya digunakan variabel dummy. Model ini sering disebut dengan model Least Square Dummy Variables (LSDV) (Ruri 2007).

\section{Metode Random Effect (REM)}

Random Effect disebabkan variasi dalam nilai dan arah hubungan antara subjek diasumsikan random yang dispesifikasikan dalam bentuk residual. Model ini mengistimasikan data panel yang variabel residual diduga memiliki hubungan antar subjek. Ruri, 2007 mengemukakan bahwa model random effect digunakan untuk mengatasi.

Untuk menentukan model mana yang terbaik antar Common Effect Model, Fixed Efect Model dan Random Effect Model maka dilakukan pengujian lebih lanjut dengan menggunakan Chow-Test atau Likehood Ratio Test dan Hausman Test. Asumsi yang digunakan dalam pengujian Chow-Test yaitu:

H0: Model mengikuti pool

Ha: Model mengikuti Fixed

Dasar pengambilan keputusan yang digunakan adalah jika probabilitas (signifikan) > 0.05, maka H0 diterima, dan sebaliknya jika Probabilitas (signifikan) $<0.05$ maka Ha ditolak. Sedangkan asumsi yang digunakan dalam pengujian Hausman Test yaitu:

H0: Model mengikuti random

Ha: Model mengikuti Fixed

Dasar pengambilan keputusan yang dipilih adalah jika Probabilitas (signifikan) $>0.05$, maka H0 diterima dan Ha ditolak, sebaliknya jika probabilitas (signifikan) < 0.05 maka H0 di tolak dan Ha diterima.

\section{Analisis Regresi Data Panel}

Persamaan regresi yang digunakan dalam analisis data panel adalah sebagai berikut:

$$
\begin{aligned}
& \mathrm{Y}_{\mathrm{It}}=\alpha+\beta_{1} \mathrm{X}_{1 \mathrm{it}}+\beta_{2} \mathrm{X}_{2} \text { it }+\beta_{3} \mathrm{X}_{3 \mathrm{it}}+\beta_{4} \mathrm{X}_{4 \mathrm{it}}+\beta_{5} \mathrm{X}_{5 \mathrm{it}}+\beta_{6} \mathrm{X}_{6 \mathrm{it}}+\mathrm{e} \\
& \text { Dimana: } \\
& \mathrm{Y}_{\mathrm{It}} \quad=\text { Harga Saham } \\
& \alpha=\text { Intercept (Konstanta) } \\
& \beta 1-\beta 6=\text { Coefficien Regresion (Parameter) } \\
& \mathrm{X}_{1} \text { it } \quad=\text { Return On Assets pada waktu } \mathrm{t} \\
& \mathrm{X}_{2} \text { it } \quad=\text { Price to book value pada waktu } \mathrm{t} \\
& \mathrm{X}_{3} \text { it = Earning Per Share pada waktu } \mathrm{t} \\
& \mathrm{X}_{4} \text { it }=\text { Debt equity ratio pada waktu } \mathrm{t} \\
& \mathrm{X}_{5} \text { it }=\text { Inflasi pada waktu } \mathrm{t} \\
& \mathrm{X}_{6} \text { it }=\text { Suku bunga sbi pada waktu } \mathrm{t}
\end{aligned}
$$




\section{Uji Hipotesis}

$$
\text { e } \quad=\text { Standar error atau Residual }
$$

Penerimaan atau penolakan hipotesis dilakukan berdasarkan kriteria sebagai berikut: (1) jika nilai signifikansi $t_{\text {hitung }}>t_{\text {tabel }} d a n \alpha<0.05$ maka hipotesis diterima (koefisien regresi signifikan). (2) jika nilai signifikansi $t_{\text {hitung }}<t_{\text {tabel }}$ dan $\alpha$ $>0.05$ maka hipotesis ditolak (koefisien regresi tidak signifikan) (Hartanto, 2004).

\section{HASIL DAN PEMBAHASAN}

\section{Uji Statistik Deskriptif Variabel Penelitian}

Tabel 2

Hasil Uji Statistik Deskriptif

\begin{tabular}{|c|c|c|c|c|c|c|c|}
\hline & $\begin{array}{l}\text { HARGA } \\
\text { SAHAM } \\
\end{array}$ & ROA & PBV & EPS & DER & INF & SBI \\
\hline Mean & 2.927060 & 0.644159 & -0.006254 & 1.801270 & -0.169845 & 0.520853 & 0.779371 \\
\hline Median & 2.760543 & 0.673411 & 0.006461 & 1.654216 & -0.116348 & 0.525045 & 0.770852 \\
\hline Maximum & 4.462598 & 1.268812 & 0.906874 & 3.118807 & 0.262451 & 0.557507 & 0.851258 \\
\hline Minimum & 1.921436 & -0.958607 & -0.823909 & 0.252853 & -1.154902 & 0.480007 & 0.716003 \\
\hline Std. Dev. & 0.643678 & 0.392596 & 0.351986 & 0.695988 & 0.324538 & 0.032021 & 0.055971 \\
\hline Observations & 66 & 66 & 66 & 66 & 66 & 66 & 66 \\
\hline
\end{tabular}

Sumber : data diolah, Eviews 8

Pada tabel 2 menunjukkan angka-angka deskriptif dari masing-masing variabel dengan jumlah observasi sebanyak 66 (enam puluh enam). Penjelasan dari analisis deskriptif adalah sebagai berikut :

1. Harga saham yang merupakan variabel terikat sebagai alat ukur dapat dilihat nilai terendah (minimum) sebesar 1,92 dan nilai tertinggi (maximum) sebesar 4,46

2. Kondisi Fundamental merupakan variabel bebas dengan menggunakan ROA sebagai alat ukurnya dan dapat dilihat nilai tertinggi (maximum) sebesar 1,26 sedangkan nilai terendah (minimum) dengan nilai $-0,95$

3. Kondisi Fundamental merupakan variabel bebas dengan menggunakan PBV sebagai alat ukurnya dan dapat dilihat nilai tertinggi (maximum) sebesar 0,90 sedangkan nilai terendah (minimum) dengan nilai $-0,82$

4. Kondisi Fundamental merupakan variabel bebas dengan menggunakan EPS sebagai alat ukurnya dan dapat dilihat nilai tertinggi (maximum) sebesar 3,11 sedangkan nilai terendah (minimum) dengan nilai 0,25

5. Kondisi Fundamental merupakan variabel bebas dengan menggunakan DER sebagai alat ukurnya dan dapat dilihat nilai tertinggi (maximum) sebesar 0,26 sedangkan nilai terendah (minimum) dengan nilai $-1,15$

6. Variabel inflasi mempunyai nilai tertinggi (maximum) secara keseluruhan sebesar 0,55 sedangkan nilai terendah (minimum) secara keseluruhan dengan nilai 0,48

7. Variabel suku bunga sbi mempunyai nilai tertinggi (maximum) dari keseluruhan dengan nilai 0,85 sedangkan nilai terendah (minimum) secara keseluruhan sebesar 0,71 


\section{Regresi Data Panel}

\section{Tabel 3}

Hasil Estimasi Random Effect Model

Dependent Variable: HARGASAHAM

Method: Panel EGLS (Cross-section random effects)

Date: 10/29/18 Time: 14:12

Sample:2015 2017

Periods included: 3

Cross-sections included: 22

Total panel (balanced) observations: 66

Swamy and Arora estimator of component variances

\begin{tabular}{|c|c|c|c|c|}
\hline Variable & Coefficient & Std. Error & t-Statistic & Prob. \\
\hline $\mathrm{C}$ & 1.124843 & 0.183770 & 6.120916 & 0.0002 \\
\hline $\mathrm{ROA}$ & 1.023955 & 0.048135 & 21.27245 & 0.0000 \\
\hline PBV & 0.764496 & 0.043216 & 17.69002 & 0.0000 \\
\hline EPS & 1.054595 & 0.033691 & 31.30163 & 0.0000 \\
\hline DER & -0.188224 & 0.049436 & -3.807439 & 0.0003 \\
\hline INF & 0.379664 & 0.232118 & 1.635650 & 0.1072 \\
\hline SBI & 0.432733 & 0.145123 & 2.981836 & 0.0042 \\
\hline \multicolumn{5}{|c|}{ Effects Specification } \\
\hline & & & S.D. & Rho \\
\hline Cross-section random & & & 0.061421 & 0.5579 \\
\hline Idiosyncratic random & & & 0.054671 & 0.4421 \\
\hline \multicolumn{5}{|c|}{ Weighted Statistics } \\
\hline R-squared & 0.961917 & \multirow{5}{*}{\multicolumn{2}{|c|}{$\begin{array}{l}\text { Mean dependent var } \\
\text { S.D. dependent var } \\
\text { Sum squared resid } \\
\text { Durbin-Watson stat }\end{array}$}} & 1.337898 \\
\hline Adjusted R-squared & 0.958044 & & & 0.302180 \\
\hline S.E. of regression & 0.061896 & & & 0.226038 \\
\hline F-statistic & 248.3717 & & & 1.980132 \\
\hline Prob(F-statistic) & 0.000000 & & & \\
\hline \multicolumn{5}{|c|}{ Unweighted Statistics } \\
\hline R-squared & 0.981365 & \multirow{2}{*}{\multicolumn{2}{|c|}{$\begin{array}{l}\text { Mean dependent var } \\
\text { Durbin-Watson stat }\end{array}$}} & 2.927060 \\
\hline Sum squared resid & 0.501857 & & & 1.439455 \\
\hline
\end{tabular}

Sumber : data diolah, Eviews 8

Berdasarkan hasil analisis regresi data panel didapatlah persamaan pengaruh ROA, PBV, EPS, DER, INF, dan SBI terhadap harga saham berikut ini: $\mathrm{Y}=1,12+1,02 \mathrm{ROA}+\mathbf{0 , 7 6 P B V}+1,05 \mathrm{EPS}-0,18 \mathrm{DER}+0,37 \mathrm{INF}+0,43 \mathrm{SBI}$

Analisis regresi data panel dalam penelitian ini menggunakan model random effect sebagai metode analisis data panel. Dari hasil regresi diperoleh nilai koefisien ROA sebesar 1,023 dengan nilai probability sebesar $0,0000<0,05$ yang berpengaruh signifikan, nilai koefisien PBV sebesar 0,764 dengan nilai probability sebesar $0,0000<0,05$ yang berpengaruh signifikan, nilai koefisien EPS sebesar 1,054 dengan nilai probability sebesar $0,0000<0,05$ yang berpengaruh signifikan, nilai koefisien DER sebesar -0,188 dengan nilai probability sebesar $0,0003<0,05$ yang berpengaruh signifikan, nilai koefisien INF sebesar 0,379 dengan nilai probability sebesar 0,1072>0,05 yang berpengaruh tidak signifikan, dan nilai koefisien SBI sebesar 0,432 dengan nilai probability sebesar 0,0042<0,05 yang berpengaruh signifikan. 
Nilai Adj. R-Square sebesar 0,958 $(95,8 \%)$ yang artinya variabel bebas yang terdiri dari roa, pbv, eps, der, inflasi dan sbi mampu menjelaskan harga saham sebesar $95,8 \%$ dan $4,2 \%$ lagi dijelaskan oleh variabel bebas yang tidak terdapat dalam model ini.

\section{PEMBAHASAN}

\section{Pengaruh Kondisi Fundamental dengan ROA Terhadap Harga Saham}

Berdasarkan hasil pengujian menunjukkan bahwa kondisi fundamental yang dilihat dengan ROA memiliki pengaruh positif dan signifikan terhadap harga saham. Hasil ini dibuktikan dengan koefisien ROA yang bernilai 1,023 dengan tingkat signifikansi $0,0000<$ alpha $=0,05$ dengan hal ini menunjukan bahwa $\mathrm{H} 1$ diterima. Hasil ini menyatakan bahwa semakin tinggi nilai return on asset, semakin baik keadaan suatu perusahaan.

Hasil penelitian ini didukung oleh penelitian yang dilakukan oleh (Wardani \& Andarini, 2016) dengan judul Pengaruh Kondisi Fundamental, Inflasi dan Suku bunga SBI terhadap harga saham dengan hasil penelitian ROA berpengaruh positif dan signifikan terhadap harga saham.

\section{Pengaruh Kondisi Fundamental dengan PBV Terhadap Harga Saham}

Berdasarkan hasil pengujian kondisi fundamental yang dilihat dengan PBV berpengaruh positif dan signifikan terhadap harga saham. Hasil ini dibuktikan dengan koefisien PBV yang bernilai 0,764 dengan tingkat signifikansi 0,0000 < 0,05 dengan hal ini menunjukan bahwa $\mathrm{H} 2$ diterima.

Hasil penelitian ini menyatakan bahwa perubahan dalam variabel PBV akan berakibat pada perubahan harga saham, sedangkan hubungan searah (positif) menunjukkan setiap kenaikan satu satuan variabel PBV maka akan berakibat terhadap kenaikan harga saham perusahaan dalam periode tertentu.

Hasil dari penelitian ini mendukung penelitian yang dilakukan oleh (Rahmi, 2013) dengan judul Pengaruh Faktor-faktor Fundamental dan Risiko Sistematik terhadap Harga Saham dan penelitian (Suselo, 2015) dengan judul Pengaruh Variabel Fundamental dan Makro Ekonomi terhadap harga saham dengan hasil penelitian PBV berpengaruh positif dan signifikan terhadap harga saham.

\section{Pengaruh Kondisi Fundamental dengan EPS Terhadap Harga Saham}

Berdasarkan hasil pengujian kond isi fundamental yang dilihat dengan EPS berpengaruh positif dan signifikan terhadap harga saham. Hasil ini dibuktikan dengan koefisien EPS yang bernilai 1,054 dengan tingkat signifikansi 0,0000< alpha $=0,05$ dengan hal ini menunjukan bahwa $\mathrm{H} 3$ diterima.

Hasil penelitian ini menyatakan bahwa Earning per share yang tinggi menandakan bahwa perusahaan tesebut berhasil meningkatkan taraf kemakmuran investor. Jika earning per share perusahaan semakin tinggi, maka investor akan semakin tertarik untuk membeli saham tersebut, dimana hal ini akan menyebabkan peningkatan harga sahamnya.

Hasil penelitian ini memberikan signal bagi perusahaan agar dapat terus meningkatkan earning per sharenya karena investor cenderung memerhatikan earning per share sebagai rasio yang dapat memengaruhi besar kecilnya harga saham. Penelitian ini menemukan hasil yang sama dengan peneitian Safitri, (2013) dengan judul Pengaruh EPS, PER, ROA, DER dan MVA terhadap Harga 
Saham dengan hasil penelitian EPS berpengaruh positif dan signifikan terhadap harga saham.

Pengaruh Kondisi Fundamental dengan DER Terhadap Harga Saham

Dari hasil pengujian kondisi fundamental yang dilihat dengan DER berpengaruh negatif dan signifikan terhadap harga saham. Hasil ini dibuktikan dengan koefisien DER yang bernilai -0,188 dengan tingkat signifikansi $0,0003<$ alpha $=0,05$ dengan hal ini menunjukan bahwa $\mathrm{H} 4$ diterima.

Hal ini menunjukkan nilai yang lemah dan negatif antara DER dengan harga saham. Jika DER mengalami kenaikan maka harga saham justru mengalami penurunan dan sebaliknya jika DER mengalami penurunan maka harga saham mengalami kenaikan.

Hasil penelitian ini sesuai dengan teori yang dikemukakan (Sudana, 2011) bahwa penggunaan utang yang semakin besar dibandingkan dengan modal sendiri akan berdampak pada penurunan nilai perusahaan. DER yang tinggi menunjukkan tingginya ketergantungan permodalan perusahaan terhadap pihak luar, sehingga beban perusahaan juga semakin berat. Jika beban hutang perusahaan tinggi atau melebihi modal sendiri yang dimiliki, maka harga saham perusahaan akan menurun. Hasil penelitian ini sama dengan penelitian yang dilakukan (Ratih, 2013) dengan judul Pengaruh EPS, PER, DER ROE terhadap harga saham pada perusahaan sektor pertambangan yang terdaftar di BEI dengan hasil penelitian DER berpengaruh negatif dan signifikan terhadap harga saham.

\section{Pengaruh Inflasi Terhadap Harga Saham}

Hasil penelitian koefisien inflasi yang bernilai 0,379 dengan tingkat signifikansi $0,1072>$ alpha $=0,05$ berpengaruh positif dan tidak signifikan terhadap harga saham. Dengan demikian dapat dinyatakan bahwa H5 ditolak. Nilai koefisien inflasi adalah sebesar 0,379 menunjukkan bahwa setiap kenaikan 1 persen tingkat inflasi akan menaikkan harga saham sebesar 0,379 persen.

Hal ini berarti investor tidak terlalu memperhatikan tingkat inflasi dalam melakukan investasi saham karena tingkat inflasi selama periode 2015-2017 tidak terlalu tinggi dan masih dapat diterima.

Hasil penelitian ini sejalan dengan penelitian yang dilakukan oleh (Dek, Roshita, Gede, \& Artini, 2016) dengan judul pengaruh suku bunga sbi, inflasi dan fundamental perusahaan terhadap harga saham indeks LQ-45 di BEI dan penelitian (Mardiyati, 2013) dengan judul pengaruh nilai tukar, suku bunga dan inflasi terhadap indeks harga saham perusahaan properti dengan hasil penelitian inflasi berpengaruh positif dan tidak signifikan terhadap harga saham.

\section{Pengaruh Suku Bunga SBI Terhadap Harga Saham}

Hasil penelitian koefisien suku bunga sbi yang bernilai 0,432 dengan tingkat signifikansi $0,0042>$ alpha $=0,05$ berpengaruh positif dan signifikan harga saham. Dengan demikian dapat dinyatakan bahwa H6 diterima.

Menurut teori analisis fundamental dikatakan bahwa peningkatan suku bunga SBI diikuti dengan peningkatan suku bunga simpanan akan menyebabkan investor cenderung mengalihkan dananya dalam bentuk simpanan deposito dengan pendapatan/return yang lebih tinggi dan tingkat risiko yang lebih rendah daripada berinvestasi pada saham (Tandeliin, 2010). Peningkatan suku bunga SBI akan menyebabkan investor enggan untuk berinvestasi pada saham sehingga permintaan saham akan berkurang dan mengakibatkan penurunan harga saham. 
Hasil penelitian ini sama dengan penelitian yang dilakukan oleh (Aurora, 2013) tentang pengaruh tingkat inflasi, tingkat suku bunga sbi dan nilai tukar rupiah terhadap indeks harga saham gabungan di bursa efek indonesia yang mengatakan semakin besar tingkat suku bunga SBI maka indeks harga saham akan turun. Dengan hasil penelitian suku bunga sbi berpengaruh positif dan signifikan terhadap harga saham.

\section{SIMPULAN}

Hasil dari penelitian pengaruh Kondisi Fundamental, Inflasi dan Suku Bunga Sertifikat Bank Indonesia terhadap Harga Saham dapat disimpulkan sebagai berikut:

1. Return On Asset (ROA) berpengaruh positif dan signifikan terhadap harga saham. Hal ini menunjukkan bahwa nilai t hitung > t tabel $(21,27245>$ $1,99773)$ dan nilai signifikansi lebih kecil dari $0,05(0,0000<0,05)$.

2. Price to Book Value (PBV) berpengaruh positif dan signifikan terhadap harga saham. Hal ini menunjukkan bahwa nilai t hitung $>\mathrm{t}$ tabel $(17,69002$ $>1,99773)$ dan nilai signifikansi lebih kecil dari $0,05(0,0000<0,05)$.

3. Earning Per Share (EPS) berpengaruh positif dan signifikan terhadap harga saham. Hal ini menunjukkan nilai t hitung>t tabel $(31,30163>$ $1,99773)$ dan nilai signifikansi lebih kecil dari $0,05(0,0000<0,05)$.

4. Debt Equity Ratio (DER) negatif dan signifikan terhadap harga saham. Hal ini menunjukkan bahwa nilai t hitung $>$ t tabel $(-3.807439>1,99773)$ dan nilai signifikansi lebih kecil dari $0,05(0,0003<0,05)$.

5. Inflasi berpengaruh positif dan tidak signifikan terhadap harga saham. Hal ini menunjukkan bahwa nilai t hitung > t tabel $(1,635650<1,99773)$ dan nilai signifikansi lebih besar dari 0,05 $(0,1072>0,05)$.

6. Suku Bunga SBI berpengaruh positif dan signifikan terhadap harga saham. Hal ini menunjukkan bahwa nilai t hitung $>\mathrm{t}$ tabel $(2,981836<1,99773)$ dan nilai signifikansi lebih kecil dari $0,05(0,0042<0,05)$.

\section{UCAPAN TERIMA KASIH}

Selesainya penulisan ini, karena penulis banyak menerimamasukan dan dorongan baik motivasi secara moral atau spiritual. Oleh karena itu penulis ingin mengucapkan terimakasih kepada:

1. Bapak Febryandhie Ananda, SE, M.Si. selaku ketua STIE 'KBP" Padang

2. Ibu Febsri Susanti, SEI, MM. selaku ketua Program Studi Manajemen

3. Ibu Aminar Sutra Dewi, SE, M.Si. sebagai dosen pembimbing dalam pembuatan skripsi ini dan penulis banyak berterimakasih atas kesabaran, kepedulian dan kesempatan yang ibu sudah diberikan, penulis berharap kebaikan ibu bisa dibalas oleh Tuhan Yang Maha Esa

4. Bapak Irdha Yusra, S.E, M.Sc sebagai penasehat akademik program studi manajemen.

5. Seluruh bagian yang sudah banyak menolong penulis yang tidak dapat penulis sampaikan satu persatu. 


\section{DAFTAR PUSTAKA}

Afriyeni, A., \& Marlius, D. (2017). Analisis Pengaruh Harga Saham Perdana Terhadap Abnormal Return Yang Diterima Investor Studi Pada Bursa Efek Indonesia. https://doi.org/10.31219/osf.io/8z7hx

Afriyeni, A., \& Marlius, D. (2018). Analisis Pengaruh Informasi Prospektus Perusahaan Terhadap Initial Return Saham Pada Pasar Perdana Di Bursa Efek Indonesia. https://doi.org/10.31219/osf.io/kt6c4

Afriyeni, A., \& Marlius, D. (2019). Analisis Faktor-Faktor Yang Berpengaruh Terhadap Ketepatan Waktu Penyampaian Laporan Keuangan Pada Perusahaan Yang Listing Di Bursa Efek Indonesia. https://doi.org/10.31219/osf.io/rv4qf

Afriyeni, A., \& Marlius, D. (2019). Analisis Tingkat Pengembalian Dan Risiko Investasi (Studi Pada Industri Manufaktur Yang Terdaftar Di Bursa Efek Indonesia). https://doi.org/10.31219/osf.io/cfb92

Almas, H. (2007). Analisis Faktor Fundamental Dan Risiko Sistematik Terhadp Harga Saham Properti Di Bursa Efek Jakarta. Tesis Sekolah Pascasarjana.

Aurora, Tona dan Agus Riyadi. 2013. Pengaruh Inflasi, Suku Bunga, dan Kus Terhadap Indeks LQ-45 di Bursa Efek Indonesia (BEI) Periode Tahun 2007-2011. Jurnal Dinamika Manajemen. Vol.1 No.3. Hal 183-197.

Budialim, Geovanni. 2013. Pengaruh Kinirja Keuangan dan Risiko Terhadap Return Saham Perusahaan Sektor Consumer Goods di Bursa Efek Indonesia Periode 2007-2011. Jurnal Ilmiah, Universitas Surabaya, Vol. 2, No. 1.

Dek, A., Roshita, I., Gede, L., \& Artini, S. (2016). Pengaruh Suku Bunga SBI, Inflasi, Dan Fundamental Perusahaan Terhadap Harga Saham Indeks LQ-45 Di BEI, 5(4), 2484-2510.

Fahruri, A. (2017). Pengaruh Corporate Governance, Loan to Deposit Ratio, Non Performing Loan, Inflasi dan Kus Terhadap Kiinerja Keuangan Perusahaan Perbankan yang Terdaftar di Bursa Efek Indonesia pada Tahun 2007-2010, $X V(1), 63-70$.

Hartanto. (2004). Penerapan Uji - T (Dua Pihak) Dalam Penelitian Peternakan ( An Aplikation Of The T - Test ( Two Tails ) In Animal Science, 29(4), 220224.

Husnan, Suad. 2009. Dasar-dasar Teori Portofolio \& Analisis Sekuritas. Edisi Keempat. Yogyakarta: UPP STIM YKJPN.

Hutami, R. P. (2012). Pengaruh Dividend Per Share, Return On Equity Dan Net Profit Margin Terhadap Harga Saham Peruwsahaan Industri Manufaktur Yang Tercatat Di Bursa Efek Indonesia Periode 2006-2010. Jurnal 
Nominal, I(1), 104-123. Purwanto. (2006). Ekonomi SMA X. Jakarta: Tunas Melati.

Itabillah, E.A. 2013. Pengaruh CR, QR, NPM, ROA, EPS,ROE, DER dan PBV Terhadap Harga Saham Perusahaen Property Dan Real Estate Yang Terdaftar Di BEI. Jurnal UMRAH, Universitas Maritim Raja Ali Haji. Pp. $1-18$.

Kasmir. 2012. Analisis Laporan Keuangan. Cetakan Keenam. PT Raja Grafindo, Jakarta

Liauw, J.S dan Trisnasidi W. 2012. Analisis Pengaruh Tingkat Inflasi, Tingkat Suku Bunga SBI, dan Nilai Tukar Rupiah Terhadap Indeks Harga Saham Gbungan (IHSG) di Bursa Efek Indonesia. STIE MDP.pp 1-8.

Perdana, D. Putra. 2009. Pengaruh Suku Bunga Sertifikat Bank Indonesia dan Kurs Rupiah Serta Inflasi Terhdap Harga Saham. Studi Kasus, Fakultas Ekonomi, Universitas Gunadarma, Jakarta.

Ratih, Dorothea, Apriatni E.P, dan Saryadi. 2013. Pengaruh EPS, PER, DER, ROE Terhadap Harga Saham pada Perusahaan Pertambangan yang Terdaftar di Bursa Efek Indnesia (BEI) Tahun 2010-2012. Diponegoro Journal of Social and Politic. pp 1-12.

Rahmi, A., Arfan, M., \& Jalaluddin. 2013. Pengaruh Faktor-Faktor Fundamental Dan Risiko Sistematik terhadap Harga Saham (Studi pada Perusahaan Manufaktur yang Terdaftar di Bursa Efek Indonesia Periode 2007-2009), Jurnal Akuntansi Pascasarjana Universitas Syiah Kuola. Vol. 2, No. 2, pp. $1-15$.

Ruri, S. (2007). Pengaruh Keputusan Investesi, Keputusan Pendanan dan Tingkat Suku Bunga Terhadap Nilai Prusahaan, 1-10.

Sarono, D. Y. (2014). Pengaruh Inflasi, Tingkat Suku Bunga SBI Dan Nilai Tukar Dollar Terhadap Harga Saham Preperti Yang Terdaftar Dalam LQ45 Di Bursa Efek Indonesia, 1-17.

Sihaloho, Lidra. 2013. Pengaruh Inflasi, Suku Bunga, dan Book Value (BV) Terhadap Harga Saham Prusahaaan Indeks LQ45 yang Terdaftar di Bursa Efek Indonesia (BEI) pada Tahun 2008-2011. Skripsi Jurusan Manajemen Fakults Ekonomi Universitas Negeri Semarang.

Sudana, I Made. 2011. Manajemen Keuangan Perusahaan Teori dan Praktek. Jakarta: Erlangga.

Sugiyono. (2015). Statistik Nonparametris Untuk Penelitian (Bayu Rahma). Alfabeta Bandung. 
Suselo, D.,d. (2015). Pengaruh Variabel Fundamental dan Makro Ekonomi terhadap Harga Saham ( Studi pada Perushaan yang Masuk dalam Indeks LQ45 ). Jurnal Aplikasi Manajemen, 104(1), 104-116.

Tandelilin, Eduardus (2010) Portofolio dan Investasi : Teori dan Aplikasi. Edisi 1. Yogyakarta: Kanisius.

Thobarry, Ath, Achmad. 2009. Analisis Pengaruh Nilai Tukar, Suku Bunga, Laju Inflasi, dan Pertumbuhan GDP Terhdap Indeks Harga Saham Sektor Prpperti. Tesis Magister Manajemen, Universitas Diponegoro, Semarang.

Viska, V. Y., \& Dewi, A. S. (2018). Pengaruh Tingkat Inflasi, Suku Bunga Dan Nilai Kurs Dollar As Terhadap Indeks Harga Saham Gabungan Pada Bursa Efek Indonesia (BEI) Periode 2011-2015. https://doi.org/10.31219/osf.io/szfdh

Wardani, D. K., \& Andarini, D. F. T. (2016). Pengaruh Kondisi Fundamental, Inflasi, Dan Suku Bunga Sertifikot Bank Indonesia Terhadap Harga Saham ( Study Kasus pada Perusahaan Real Estate dan Property yang terdftar di Bursa Efek Indonesia tahun 2010-2013 ). Akuntansi, 4(2), 77-90.

Widaningsih. 2013. Pengaruh Return On Assets (ROA), Debt to Equity Ratio (DER), Earning Per Share (EPS) dan Dividan Per Share (DPS) Terhadap Harga Saham (Studi Pada Perusahaan Indeks LQ 45 yang Terdaftar di Bursa Efek Indonesia Periode 2010-2011). Jurnal Manajemen, ppp: 1-15.

Winarno, W. W. (2015). Analisis Ekonometrika dan statistika dengan Eviews (4th etd.). Yogyakarta. 